\title{
COVID-19 ile Yaşanan Sosyal İzolasyonun Aile ve Evlilik Yaşamına Yansımaları: Fenomenolojik Bir Çalışma
}

\section{Reflections of Social Isolation Experienced by COVID-19 on Family and Marital Life: A Phenomenological Study}

\author{
Yunus Kaya *1, Rabiye Akın Işık ${ }^{2}$
}

\begin{abstract}
Introduction: The COVID-19 pandemic has negatively impacted individuals not only physically, but also mentally, socially and economically. These difficulties that occur in the lives of individuals can also have negative effects on family and marital life. Method: This study was conducted using a phenomenological qualitative research method to evaluate the impact of social isolation experienced with COVID-19 on family and marital life. The data were collected using the Introductory Features Information Form and Semi-Structured Open Ended In-depth Individual Interview Question Form. Research data were collected from 15 married individuals. The qualitative data were evaluated using method of thematic analysis. Results: The mean age of participants were $37.00 \pm 7.88$ years, mean duration of marriage of participants were $11.15 \pm 8.97$ years. As a result of the analysis of qualitative data, two categories were obtained, namely, "The Negative Effects of the COVID-19 Pandemic on Family and Marital Life" and "The Positive Effects of the COVID-19 Pandemic on Family and Marital Life". Six themes and 10 sub-themes were determined under these categories. Conclusion: As a result of the research, the themes of mental effects, effects on social and daily life, effects on children and effects on family and marital life were determined under the category of negative effects of the COVID-19 pandemic on family and marital life. Under the category of positive effects on family and marital life, the themes of changing life priorities and making sense of life and increasing sharing between spouses in marital life were obtained. For this reason, health professionals working with families, should determine the information needs and difficulties experienced of families and spouses in this process. After identifying the problems experienced, developing the coping skills of family members and effective communication skills with in the family and between spouses will minimize the negative effects of the COVID-19 pandemic on family and marital life. In this context, planning and implementing necessary protective and reinforcing interventions for families will contribute to increase satisfaction in family and marital life.
\end{abstract}

Key words: COVID-19, social isolation, family, marriage, qualitative study

\section{ÖZET}

Giriș: COVID-19 pandemisi, sadece bireyleri fiziksel olarak değil aynı zamanda ruhsal, sosyal ve ekonomik olarak olumsuz etkilemiştir. Bireylerin yaşantısında meydana gelen bu zorlanmalar aile ve evlilik yaşantısı üzerinde olumsuz etkilere de yol açabilmektedir. Yöntem: Bu araştırma, COVID-19 ile yaşanan sosyal izolasyonun aile ve evlilik yaşamı üzerine etkisini değerlendirmek amacıyla fenomenolojik niteliksel araștırma yöntemi kullanılarak gerçekleștirilmiștir. Araştırma verileri, Tanıtıcı Özellikler Soru Formu ve Yarı Yapılandırılmıș Açık Uçlu Derinlemesine Bireysel Görüşme Formu kullanılarak toplanmıştır. Araştırma verileri, 15 evli bireyden toplanmıştır. Nitel veriler, tematik analiz yöntemi kullanılarak değerlendirilmiştir. Bulgular: Katılımcıların yaş ortalaması $41.73 \pm 10.52$, evlilik süreleri ise $17.33 \pm 12.43$ olarak bulunmuștur. Nitel verilerin analizi sonucunda, 'COVID-19 Pandemisinin Aile ve Evlilik Yaşantısı Üzerine Olumsuz Etkileri' ve 'COVID19 Pandemisinin Aile ve Evlilik Yaşantısı Üzerine Olumlu Etkileri’ olmak üzere iki kategori elde edilmiştir. Bu kategoriler altında 6 tema ve 10 alt tema belirlenmiştir. Sonuç: Araştırma sonucunda, COVID-19 pandemisinin aile ve evlilik yaşantısı üzerinde olumsuz etkileri kategorisi altında ruhsal etkiler, sosyal ve günlük yaşam üzerine etkiler, çocuklar üzerine etkiler ve aile ve evlilik yaşantısı üzerine etkiler temaları belirlenmiştir. Aile ve evlilik yaşamı üzerine olumlu etkiler kategorisi altında ise yaşam önceliklerinin değişmesi ve yaşamı anlamlandırma ve evlilik yaşantısında eşler arası paylaşımın artması temaları elde edilmiştir. Bu nedenle aile ile çalışan sağlık profesyonellerinin, ailelerin ve eşlerin bu süreçteki bilgi gereksinimlerini ve yaşadığı zorlukları belirlemelidir. Yaşanan sorunların belirlenmesinin ardından aile üyelerinin baş etme becerilerinin, aile içinde ve eşler arasında etkili iletişim becerilerinin geliştirilmesi, COVID-19 pandemisinin aile ve evlilik yaşamı üzerine olumsuz etkilerini en aza indirecektir. Bu bağlamda ailelere yönelik gerekli koruyucu ve güçlendirici müdahalelerin planlanması ve uygulanması aile ve evlilik yaşantısında doyumun ve memnuniyetin artmasına katkı sağlayacaktır.

Anahtar kelimeler: COVID-19, sosyal izolasyon, aile, evlilik, nitel araştırma

Received / Geliş tarihi: 04.05.2021, Accepted / Kabul tarihi: 10.06.2021

${ }^{1}$ Aksaray Üniversitesi Sağlık Bilimleri Fakültesi Çocuk Gelişimi Bölümü, AKSARAY (ORCID: 0000-0001-6485-3801)

${ }^{2}$ Hacettepe Üniversitesi Hemşirelik Fakültesi, Doğum ve Kadın Hastalıkları Hemşireliği Anabilim Dalı, ANKARA (ORCID: 0000-0003-4419-1753)

*Address for Correspondence / Yazışma Adresi: Aksaray Üniversitesi Sağlık Bilimleri Fakültesi Çocuk Gelişimi Bölümü, Aksaray-TÜRKIYE,

E-mail: yuunus.kaya@gmail.com

Tel: +90 3822882750

Kaya Y, Işık RA. COVID-19 ile Yaşanan Sosyal İzolasyonun Aile ve Evlilik Yaşamına Yansımaları: Fenomenolojik Bir Çalışma. TJFMPC, 2021;15(3):510520.

DOI: $10.21763 /$ tjfmpc. 932521 


\section{Gİiş̧}

Aralık 2019'da Çin'de SARS virüsü ile yapısal olarak ilişkili yeni bir koronavirüs (COVID-19) rapor edilmiştir., ${ }^{1,2}$ COVID-19 yüksek bulaşıcılık düzeyine sahip olması nedeniyle küresel olarak hızla

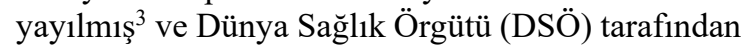
11 Mart 2020 tarihinde pandemi olarak ilan edilmiştir. ${ }^{4}$ COVID-19 pandemisinin başlamasıyla, tüm dünyada virüsün bulaşıcılığını önlemek amacıyla tedbirler alınmış ve tedbirlerle birlikte günlük yaşam hızla değişmiştir. ${ }^{5}$ Tüm dünyada, eğitim, çalışma hayatı, günlük yaşam alışkanlıkları ve sosyal faaliyetler gibi alanlar ciddi düzeyde etkilenmiştir. ${ }^{6}$ Uluslararası düzeyde, ülkeler sınırlarını kapatmış ve ekonomik faaliyetler olumsuz olarak etkilenirken, ${ }^{7}$ ulusal düzeyde ise okullar kapatılarak uzaktan eğitim uygulamalarına başlanmış, toplumsal hareketliliği kısıtlamak adına sosyal faaliyetler yasaklanmış, esnek ve evden çalışma yöntemlerine geçilmiş, 65 yaş ve üzeri ile 20 yaş altı bireylere ve zaman zaman tüm yaş gruplarına yönelik sokağa çıkma yasakları uygulanmıştır. ${ }^{8,9}$

COVID-19 salgınının yayılmasını önlemek üzere alınan en temel strateji sosyal hareketliliğin kısıtlaması ve insanların fiziksel temasının azaltılmasıdır. ${ }^{10,11}$ Ancak, günlük yaşamda meydana gelen değişimler, fiziksel ve sosyal kısıtlamalar, bireyleri biyopsikososyal olarak bütüncül anlamda olumsuz etkilemiştir. $\mathrm{Bu}$ nedenle, COVID-19 sürecinde hasta olma ve ölüm kaygısının yanı sıra günlük yaşamda meydana gelen kısıtlamalar, sosyal destek sistemlerinin kaybı, ekonomik sorunlar, iş yerlerinin kapatılması ve işten çıkarılmalar sonucunda bireyler sadece fiziksel olarak etkilememiş aynı zamanda ruhsal, sosyal ve ekonomik olarak da zorlanmıştır. ${ }^{1,5}$ Süreçte artan stres, yaşanan duygusal, ruhsal ve ekonomik zorluklar, anksiyete, depresyon ve travma sonrası stres bozukluklarına yol açarak aile ve evlilik yaşantısını olumsuz etkilemiştir. ${ }^{12-14}$

Özellikle yaşanan ruhsal zorlanmalar ve günlük rutinlerde meydana gelen değişim ev içerisinde çatışmaların ve şiddetin artmasına, evlilik yaşantısında sorunlara neden olarak evlilik doyumunda azalmaya neden olabilmektedir. ${ }^{13-15}$ Aynı zamanda kadınların, toplumsal cinsiyet rolleri doğrultusunda ev içi sorumlulukları artmış, çocukların uzaktan eğitim sürecinde, ders ve ödevlerinin takibinde, bakım ve oyun gibi gereksinimlerinin karşılanmasında daha fazla sorumluluk almışlardır. ${ }^{16}$ Dolasıyla izolasyon süreci, kadınların ev içi iş yükünün daha da artmasına neden olmakla birlikte eşlerden yeterli destek alınmadığında aile içi sorunlara da yol açabilmektedir. ${ }^{17}$ Benzer şekilde erkelerinde toplumsal cinsiyet rolleri doğrultusunda evin ekonomik sorumluluğunu üstlenme ve aile üyelerinin bakımını yerine getirmede sorumlulukları bulunmaktadır. Ancak yaşanan süreçte işten çıkarmalar, beraberinde ekonomik sorunlar ve yanı sıra yaşanan diğer sorunlar, evlilik ve aile yaşamında diğer önemli sorunlara neden olabilmektedir. $\mathrm{Bu}$ doğrultuda, COVID-19 pandemisinin yol açtı̆̆ ekonomik, ruhsal ve sosyal zorluklar, madde kullanımı, aile içi şiddet ${ }^{18,19}$ ve boşanma oranlarını arttırdığ1 belirtilmektedir. ${ }^{20,21}$ Ancak COVID-19 sürecinde yaşanan sosyal izolasyonun aile ve evlilik yaşantısında sadece olumsuz etkilere yol açmadığı, ailedeki ilişkilerin güçlenmesine ve paylaşımların artarak evlilik doyumunu artırdığına vurgu yapılmaktadır. ${ }^{22}$

Sosyal izolasyon, COVID-19'un yayılımını kontrol etme ve toplumu korumada etkin yöntem olmakla birlikte sosyal izolasyon koşulları yaşanan ruhsal, sosyal ve ekonomik stresörlerin aile ve evlilik yaşamı üzerindeki etkileri halen bilinmezliğini korumaktadır. İzolasyon sürecinde toplumun en temel yapı taşlarından olan ailenin ve eşlerin sağlının korunması aile bütünlüğünü bozabilecek olumsuzlukların belirlenerek erken dönemde koruyucu önlemlerin alınması, toplum sağlığının ve bütünlüğünün korunmasına da katkıda bulunabilecektir. Aynı zamanda salgın hastalıkların aile yaşamı açısından etkisini bilmek; koruyucu müdahalelerin planlanması için önemli olacaktır. $\mathrm{Bu}$ nedenle bu çalışma, COVID-19 ile yaşanan sosyal izolasyonun aile ve evlilik yaşamı üzerine etkilerini değerlendirecek ve devam eden izolasyon sürecinde aile içi ilişkileri olumsuz etkileyen faktörlerin belirlenmesine, koruyucu önlemlerin erken dönemde alınarak tüm topluma yaygınlaştırılmasına ve aile içi ilişkilerin kalitesinin arttırılmasına katkı sağlayacaktır.

\section{YÖNTEM}

\section{Araştırmanın Amacı}

$\mathrm{Bu}$ araştırma, COVID-19 ile yaşanan sosyal izolasyonun aile ve evlilik yaşamı üzerine etkisini değerlendirmek amacıyla fenomenolojik niteliksel araştırma yöntemi kullanılarak gerçekleştirilmiştir. Araştırma amacı doğrultusunda, 'COVID-19 pandemisi ve sosyal izolasyon sürecinin aile ve evlilik yaşamı üzerine etkisi nelerdir?' sorusuna yanıt aranmıştır.

\section{Araştırmanın Tasarımı}

Araştırma verileri, nitel araştırma yaklaşımlarından fenomenolojik araştırma deseni kullanılarak toplanmıştır. Fenomenolojik yaklaşım, bireylerin fenomen ya da fenomenlerle ilgili ortak deneyimlerini derinlemesine anlamaya çalışan, bireyin bakış açısından inceleyen ve fenomenle ilgili deneyimlerini evrensel nitelikte açıklayan araştırma yöntemidir. ${ }^{23}$ Bu çalışmada, evli çiftlerin COVID-19 
sürecinde yaşanan sosyal izolasyon dönemindeki deneyimleri 'COVID-19, sosyal izolasyon ve evli olma' fenomenleri üzerine odaklanılarak değerlendirilmiştir. $\mathrm{Bu}$ nedenle çalışma verileri, katılımcıların, fenomenler ile ilgili deneyimlerini belirlemek amaciyla evli çiftler dahil edilerek homojen amaçlı örnekleme yöntemi kullanılarak toplanmıştır. Çalışmaya dahil edilmede, katılımcıların evli olmaları, COVID-19 sosyal izolasyon sürecini eşleriyle birlikte yaşamış olmaları, en az 6 aydır evli olmaları, herhangi bir ruhsal rahatsızlıklarının olmaması ve çalışmaya katılmaya gönüllü olması kriteri aranmıştır.

\section{Veri Toplama Araçları}

Araştırma verileri, tanıtıcı özellikler soru formu ve yarı yapılandırılmış açık uçlu derinlemesine bireysel görüşme soru formu kullanılarak toplanmıştır.

\section{Tanıtıcı Özellikler Soru Formu}

Tanıtıcı özellikler soru formu katılımcıların, yaş, cinsiyet, eğitim düzeyi, meslek, gelir düzeyi, evlilik süresi, çocuk sahibi olma durumları, çocuk sayıları, sosyal izolasyon sürecinde kendilerinin ve eşlerinin aktif olarak çalışma durumlarını değerlendiren 10 sorudan oluşmaktadır.

\section{Yarı Yapılandırılmış Açık Uçlu Derinlemesine Bireysel Görüşme Formu}

Yarı yapılandırılmış açık uçlu derinlemesine bireysel görüşme, formu araştırmacılar tarafından hazırlanmış olup katılımcıların süreçteki deneyimlerini değerlendirmek amaciyla oluşturulmuştur. Soru formu katılımcıların COVID19 ve sosyal izolasyon sürecinin aile ve evlilik yaşantısı üzerine etkisini değerlendirmek amacıyla altı sorudan oluşmaktadır (Tablo-1).

\section{Verilerin Toplanması}

Araştırmanın planlanması, verilerin toplanması, analiz ve raporlama aşamasında Consolidated Criteria for Reporting Qualitative Research (COREQ) nitel araştırma rehberi kullanılmıştır. ${ }^{24}$ Araştırma verileri, daha önce nitel araştırma üzerine çalışma deneyimi olan kadın araştırmacı tarafından toplanmıştır. Katılımcılar, amaçlı ve kartopu örnekleme yöntemi ile seçilmiş ve veriler toplanmadan önce araştırmaya katılmayı kabul eden katılımcılara araştırma hakkında bilgi verilmiş ve amacı açıklanmıştır. Ardından katılımcılardan araştırmaya gönüllü olarak katıldıklarını beyan ettikleri aydınlatılmış onam formlarını okumaları istenmiş ve online olarak ardından ise nitel verilerin toplanması sırasında sözel olarak onam veren 15 katılımcı araştırmaya dahil edilmiştir. Bireysel görüşmelere başlamadan önce katılımcılara tanıtıcı özelliklerinin yer aldığı soru formu online olarak gönderilmiş ve katılımcılar tarafından doldurulmuştur. Ardından nitel veriler, derinlemesine bireysel görüşme yöntemi kullanılarak toplanmıştır. Bireysel görüşmeler için, katılımcılarla ortak görüşme günü ve saati belirlendikten sonra internet tabanlı konferans görüşme programları üzerinden görüşmeler gerçekleştirilmiştir. Katılımcılara, soruları cevaplandırmadan önce, görüşmelerin online olarak kayıt edileceği, kayıtların sadece araştırmacılar tarafından dinleneceği ve görüşmenin bir defa yapılacağı belirtilmiştir. Katılımcıların, kendilerini rahat hissetmesi ve mahremiyetin sağlanması için görüşmeler araştırmacı ve katılımcı için oluşturulan platformda üçüncü kişilerin olmadığı bir ortamda toplanmıştır. Araştırmanın güvenirliği için bütün görüşmeler aynı araştırmacı tarafından yapılmıştır. Görüşmeye başlamadan önce araştırmacı tarafından katılımcıya görüşme sürecinde sorulacak olan sorular hakkında bilgi verilerek katılımcının kendisini hazır hissettiğinde görüşmeye başlanmıştır. Katılımcının onayının ardından araştırma soruları sırasıyla sorulmuştur.

Tablo-1. Yarı Yapılandırılmış Açık Uçlu Derinlemesine Bireysel Görüşme Soru Formu

1. Koronavirüse (COVID-19) bağlı yaşadığınız sosyal izolasyon ile ilgili duygu ve düşüncelerinizden bahseder misiniz?

2. Koranavirüs (COVID-19) günlük yaşantınızı nasıl etkiledi?

3. Koronavirüs (COVID-19) süreci ve bu süreçten uygulanan sosyal izolasyon sürecinin aileniz ve evliliğiniz üzerinde etkileri neler oldu?

4. Bu süreçte evde ailenizle ve eşinizle birlikte zamanınızı nasıl geçirdiniz?

5. Bu sürecin evliliğiniz üzerinde ne tür olumsuz etkileri oldu? Bunları nasıl çözümlediniz?

6. Sizce yaşanan sosyal izolasyon dönemindeki evliliğinizi daha kaliteli ve sevgi dolu hale nasıl gelebilirdi? Nelere ihtiyaç duydunuz?

Araştırmaya başlamadan önce görüşme sorularının anlaşılırlığını test etmek ve araştırmacının süreçte dikkat etmesi gereken noktaları değerlendirmek için iki katılımcı ile pilot görüşmeler yapılmıştır. Pilot görüşmeler sonucunda 
araştırmacılar soruların anlaşılırlığını yeniden değerlendirmiş ve çalışma soruları revize etmişlerdir. Ardından araştırma verileri toplanmaya başlanmış ve araştırma verileri, Eylül 2020-Ocak 2021 tarihleri arasında toplanmıştır. Her bir bireysel görüşme en az 20 dakika, en fazla 50 dakika sürmüştür.

\section{Verilerin Analizi}

Araştırma verileri, her bir bireysel görüşme gerçekleştirildikten sonra birinci yazar tarafindan görüşmeler kelimesi kelimesine yazıya dökülmüştür. Yazıya dökülen görüşmeler sonrasında katılımcılara gönderilmiş ve katılımcılardan ifadelerin doğruluğu ve anlaşılırlığı açısından değerlendirmeleri istenmiş ve onayları alınmıştır. Ardından, araştırma verileri, tematik analiz yöntemi kullanılarak analizi gerçekleştirilmiştir. Tematik analiz, verilerin sınıflandırılması, kodların oluşturulması, temaların aranması, temaların gözden geçirilmesi, temaların tanımlanması ve verilerin raporlaştırılması olmak üzere altı basamaktan oluşmaktadır. Bu araştırmada verilerin analizini, her bir araştırmacı birbirinden bağımsız şekilde gerçekleştirmiştir. İlk olarak kelimesi kelimesine yazıya dökülen raporlar araştırmacılar tarafindan tekrarlı okunmuş, araştırmacıların görüşmeye hâkim olması sonucunda önemli ifadeler belirlenerek veriler kodlanmıştır. Önemli ifadelerin belirlenmesi sonucunda araştırmacılar birbirinden bağımsız şekilde önemli ifadeleri okumuş, temaları belirlemiş ve temaların tanımlamasını yapmışlardır. Araştırmacılar son olarak, tema ve alt temaların altına katılımcı ifadelerini yerleştirmişlerdir. Her bir araştırmacı bu süreci birbirinden bağımsız şekilde gerçekleştirdikten sonra bir araya gelmiş ve buldukları temaları karşılaştırmışlardır. Son olarak kendi aralarında görüş birliği sağlayarak tema ve alt temaların son halini vererek verilerin analizini tamamlamışlardır. Verilerin analizi sürecinde, herhangi bir yazılım programı kullanılmamış, araştırmacılar tarafindan manuel olarak gerçekleştirildi.

\section{Araştırma Verilerinin Güvenirliği}

$\mathrm{Bu}$ araştırmada verilerin güvenirliği, inandırıcılık, güvenirlik, onaylanabilirlik, aktarılabilirlik ve şeffaflı ilkeleri doğrultusunda gerçekleştirilmiştir. ${ }^{25}$ İlk olarak araştırmacılar, ruh sağlığı ve kadın sağlığı hemşireliğinde doktora düzeyinde eğitime sahiptirler ve araştırmacıların mesleki deneyimleri, kuramsal bilgileri ve gözlemleri doğrultusunda, COVID-19 pandemisi sürecinde yaşanan sosyal izolasyon, ruhsal, ekonomik ve fiziksel sorunların evlilik yaşantısı üzerinde oluşturabileceği sorunları belirlemek amacıyla araştırma planlamıştır. Güvenirliğini sağlamak için katılımcılar gönüllülük esasına dayalı olarak araştırmaya dahil edilmiş ve süreçteki deneyimlerini olabildiğince detaylandırmaları istenmiştir. Görüşmeler sırasında araştırmacılar, katılımcıların deneyimlerini, duygularını ve düşüncelerini onaylamak ya da reddetmek gibi bir tutum içerisine girmeden tarafsız bir şekilde dinlemişlerdir. Böylelikle katılımcılar, deneyimlerini özgürce belirtmişlerdir. Her bir bireysel görüşme tamamlandıktan sonra kelimesi kelimesine yazıya dökülen görüşmeler katılımcılara geri gönderilmiş, ifadelerin doğruluğunu ve anlaşılırlığını kontrol etmeleri istenmiştir. İfadelerin doğruluğu ve anlaşılırlı̆̆ verilerin analizi yapılmıştır. Araştırmanın güvenirliğini artırmak için araştırmacılar tematik analiz sürecini birbirinden bağımsız şekilde gerçekleştirmişlerdir.

\section{Etik Uygunluk}

Araştırmanın etik uygunluğu, İnsan Araştırmaları Etik Kurulu tarafindan (22.06.2020 tarih ve 2020/06-48) onaylanmıştır. T.C. Sağlık Bakanlığı'ndan araştırmanın yapılabilmesi için gerekli izinler alınmıştır (2020-06-13T11_24_42). Etik kurul onayının ardından, çalışmaya katılan tüm katılımcılara araştırma hakkında bilgi verilerek bilgilendirilmiş onamları alınmıştır.

\section{BULGULAR}

Araştırma verilerinin analizinde, öncelikle katılımcıların tanıtıcı özellikleri değerlendirilmiştir. Katılımcıların, yaş ortalaması 41.73 10.52 (Min: 26, Max:67) olarak bulunmuştur. Katılımcıların, \%80'i kadın, \%33.3'ü lise düzeyinde eğitime sahip, $\% 46.7$ 'si ev hanımı ve \%66.7'si ekonomik durumunun geliri giderine eşit olarak bulunmuştur. Katılımcıların aile ve evlilik yaşantısı ile ilgili tanıtıcı özellikler değerlendirildiğinde, evlilik süreleri 17.33 \pm 12.43 (Min:1, Max: 44), tamamı çocuk sahibi olduğunu, \%46,7'si bir çocuğunun olduğunu, \%73,3'ü kendisi ve \%66,7'si ise eşlerinin bu süreçte aktif olarak çalışmadığını belirtmiştir (Tablo-2).

Nitel görüşmeler sonucunda elde edilen verilerin analizi sonucunda, COVID-19 pandemisinin aile ve evlilik yaşantısı üzerine olumsuz ve olumlu etkileri olmak üzere iki kategori belirlenmiştir. COVID-19 pandemisinin aile ve evlilik yaşantısı üzerine olumsuz etkileri kategorisi altında 4 tema ve 10 alt tema bulunurken, olumlu etkileri kategorisi altında ise 2 tema ortaya çıkmıştır (Tablo-3). Kategoriler altında ortaya çıkan tema ve alt temalara ilişkin bulgular aşağıda verilmiştir. 
Tablo-2. Katılımcıların Tanıtıcı Özellikleri

\begin{tabular}{|c|c|c|c|}
\hline \multicolumn{2}{|l|}{ Tanıtıcı Özellikler } & \multirow{2}{*}{\begin{tabular}{|l|} 
Sayı $(\mathbf{n}=\mathbf{1 5})$ \\
$41.73 \pm 10.52$
\end{tabular}} & \multirow{2}{*}{$\begin{array}{l}\text { Yüzde (\%) } \\
\text { Min: } 26 \text { - Max: } 67\end{array}$} \\
\hline Yaş & $\mathrm{X} \pm \mathrm{SS}$ & & \\
\hline \multirow[t]{2}{*}{ Cinsiyet } & Kadın & 12 & 80.0 \\
\hline & Erkek & 3 & 20.0 \\
\hline \multirow{4}{*}{ Eğitim düzeyi } & İlkokul & 4 & 26.7 \\
\hline & Ortaokul & 2 & 13.3 \\
\hline & Lise & 5 & 33.3 \\
\hline & Üniversite & 4 & 26.7 \\
\hline \multirow[t]{4}{*}{ Meslek } & Ev Hanımı & 7 & 46.7 \\
\hline & Kamu Personeli & 3 & 20.0 \\
\hline & Özel Sektör & 3 & 20.0 \\
\hline & Emekli & 2 & 13.3 \\
\hline \multirow[t]{3}{*}{ Gelir düzeyi } & Geliri Giderinden $\mathrm{Az}$ & 4 & 26.7 \\
\hline & Geliri Giderine Eşit & 10 & 66.7 \\
\hline & Geliri Giderinden Fazla & 1 & 6.6 \\
\hline Evlilik süresi & $\mathrm{X} \pm \mathrm{SS}$ & $17.33 \pm 12.43$ & Min: 1- Max: 44 \\
\hline \multirow[t]{2}{*}{ Çocuk sahibi olma } & Evet & 15 & 100.0 \\
\hline & Hayır & 0 & 0.0 \\
\hline \multirow{3}{*}{ Çocuk sayısı } & Bir & 7 & 46.7 \\
\hline & İki & 6 & 40.0 \\
\hline & Üç & 2 & 13.3 \\
\hline \multirow{2}{*}{$\begin{array}{l}\text { Süreçte aktif olarak } \\
\text { çalıştınız mı? }\end{array}$} & Evet & 4 & 26.7 \\
\hline & Hayır & 11 & 73.3 \\
\hline \multirow{2}{*}{$\begin{array}{l}\text { Eşiniz süreçte aktif } \\
\text { olarak çalıştı mı? }\end{array}$} & Evet & 10 & 66.7 \\
\hline & Hayır & 5 & 33.3 \\
\hline
\end{tabular}

Tablo-3. Bireysel Görüşme Sonucunda Elde Edilen Kategori, Tema ve Alt Temalar

\begin{tabular}{|c|c|c|}
\hline Kategori & Tema & Alt Tema \\
\hline \multirow{10}{*}{$\begin{array}{l}\text { COVID-19 Pandemisinin Aile ve } \\
\text { Evlilik Yaşantısı Üzerine Olumsuz } \\
\text { Etkileri }\end{array}$} & \multirow[t]{3}{*}{ Ruhsal Etkiler } & $\begin{array}{l}\text { Hasta Olma ve Sevdiklerine } \\
\text { Bulaştırma Kaygısı }\end{array}$ \\
\hline & & Belirsizlik \\
\hline & & Tedirginlik ve Korku \\
\hline & \multirow{2}{*}{$\begin{array}{l}\text { Sosyal ve Günlük Yaşam Üzerine } \\
\text { Etkiler }\end{array}$} & Sosyal Etkileşimde Bozulma \\
\hline & & $\begin{array}{l}\text { Günlük Yaşam Alışkanlıklarının } \\
\text { Değişmesi }\end{array}$ \\
\hline & \multirow[t]{2}{*}{ Çocuklar Üzerine Etkiler } & $\begin{array}{l}\text { Çocuklarda Ruhsal ve Davranışsal } \\
\text { Sorunlar }\end{array}$ \\
\hline & & $\begin{array}{l}\text { Çocukların Eğitim Yaşantısında } \\
\text { Sorunlar }\end{array}$ \\
\hline & \multirow{3}{*}{ Aile Yaşantısı Üzerine Etkiler } & Aile içi Etkileşimde Bozulma \\
\hline & & Çatışma \\
\hline & & Ekonomik Sorunlar \\
\hline \multirow{2}{*}{$\begin{array}{l}\text { COVID-19 Pandemisinin Aile ve } \\
\text { Evlilik Yaşantısı Üzerine Olumlu } \\
\text { Etkileri }\end{array}$} & $\begin{array}{l}\text { Yaşam Önceliklerinin Değişmesi } \\
\text { ve Yaşamı Anlamlandırma }\end{array}$ & \\
\hline & Eşler Arası Paylaşımın Artması & \\
\hline
\end{tabular}


Kategori-1: COVID-19 Pandemisinin Aile ve Evlilik Yaşantısı Üzerine Olumsuz Etkileri

Bu kategori altında, ruhsal etkiler, sosyal ve günlük yaşam üzerine etkiler, çocuklar üzerine etkiler ve aile yaşamı üzerine etkiler olmak üzere 4 tema elde edilmiş, bu temalara ilişkin bulgular aşağıda verilmiştir.

\section{Tema-1: Ruhsal Etkiler}

$\mathrm{Bu}$ tema altında, hasta olma ve sevdiklerine bulaştırma kaygısı, belirsizlik, tedirginlik ve korku alt temaları elde edilmiştir. Alt temalara ilişkin bulgular aşağıda verilmiştir.

\section{Alt Tema-1: Hasta Olma ve Sevdiklerine Bulaştırma Kaygısı}

$\mathrm{Bu}$ alt temada katılımcilar, COVID-19 pandemisi sürecinde hasta olma ve hastalığı sevdiklerine bulaştırma ile ilgili yüksek düzeyde kayg1 yaşadıklarını belirtmişlerdir. $\mathrm{Bu}$ nedenle, sürekli temizlik yaptıklarını, dışardan aldıkları ürünleri sürekli temizlediklerini, hijyen uygulamalarına oldukça dikkat ettiklerini, sevdikleri ve sosyal çevreleriyle görüşmediklerini ve ev dışına çıkmak zorunda kalan aile üyelerinin eve hastalık taşıma olasılıklarına yönelik yüksek düzeyde kayg1 yaşadıklarını belirtmişlerdir. Aynı zamanda katılımcılar, kendilerinin hasta olma durumunda evdeki diğer aile üyelerine ve yaşlı olan ebeveynlerine hastalık bulaştırmaya yönelik kaygı yaşadıklarını aktarmışlardır. K-11 kodlu katılımcı süreçteki deneyimlerini şu şekilde aktarmıştır:

Kıyafetleri daha yüksek derecede yıkıyorum, marketten aldıklarımı direkt balkona attyorum, bir gece orada duruyor. Çocuklar geliyor, ellerinizi hemen yıkayın diyorum. Önceden de diyordum ama şimdi daha fazla söylemeye başladım. Aslında çocuklar çok fazla etkilendi, çok sikıldı ve bunaldilar. Ama bunlarl da yapmasan bu seferde hastallk gelir mi gelmez mi korkusu oluyor. Bir öksürüyorsun, burnun aklyor, ateşlendim mi ben, korona mi oldum acaba diyorsun. Psikolojik ve duygusal olarak çok etkilendik. Bu duygulardan nasıl siyrılacă̆ız bilmiyorum. Mesela çocuklar, gece üstünü açıp üşüttüklerinde, sabah anne ben ateşli miyim yoksa korona mı oldum? Korona hayatımıza girdiğinden beri hayatımız alt üst oldu.

\section{Alt Tema-2: Belirsizlik}

$\mathrm{Bu}$ alt temada katılımcılar, sürecin başından beri belirsizlikle iç içe olduklarını, beklenmeyen bir durum olduğunu, bazı hastalık semptomlarının COVID-19 semptomları ile karıştığını, bulaş yolları, COVID-19'a yakalanma durumunda sürecin nasıl olacağ 1 , kalıcı bir hasarın kalıp kalmayacağ $\breve{1}_{1}$ ve sürecin nasıl devam edeceği gibi birçok konuda belirsizlik yaşadıklarını belirtmişlerdir. K-3 kodlu katılımcı yaşadığı belirsizliği şu şekilde ifade etmiştir:

Beklenmedik bir süreçti açıkçası. Kendim ve ailem adına kimse tabii ki böyle bir durumu beklemiyordu. Panik havasında gelişti, ilk başta çok panikledik hani ne yapacağımızı bilmediğimiz için nasıl bir durumun içinde olduğumuzu tam olarak kestiremedik. Sürekli bir korku vardı içimizde acaba hasta mıyız değil miyiz ya da en küçük bir belirti de, gribal bir enfeksiyon belirtisinde acaba biz COVID19 'mu olduk şeklinde tepkilerimiz oldu. Nasil bulaşacağını tam olarak bilmediğimiz için o dönemde herkeste bir bilgi eksikliği vardl.

\section{Alt Tema-3: Tedirginlik ve Korku}

$\mathrm{Bu}$ alt temada katılımcılar, COVID-19 süreci uzadıkça tedirginlik ve korku duygularının arttığını, artık rahat rahat dışarı çıkamadıklarını, hasta olurlarsa, özellikle çocuğu olan ebeveynler çocuklarına ne olacağına yönelik tedirginlik ve korku hissettiklerini belirtmişlerdir. K-6, süreçte yaşadığı korku ve tedirginliği şu şekilde belirtmiştir:

Başta çok korkmamıştım, sonra yaygınlaşmaya başlayınca korkum başladı. Özellikle COVID-19 olduktan sonra ruhsal olarak çok etkilendim ve üzüldüm. Bir çocuğum var ve hastaneye yatarsam, ona bulaştırırsam diye korkuyordum. Hastaneye yatmadım ama benden beş gün sonra eşimde, kızımda pozitif olunca daha çok stres oldum. Kızımda ateș oldu, kötü olursa hastaneye yatırırlarsa hani ne yaparı diye çok bunalıma girdim.

Tema-2: Sosyal ve Günlük Yaşam Üzerine Etkiler

$\mathrm{Bu}$ tema altında, sosyal etkileşimde bozulma ve günlük yaşam alışkanlıklarının değişmesi alt temaları elde edilmiştir. Alt temalara ilişkin bulgular aşağıda verilmiştir.

\section{Alt Tema-1: Sosyal Etkileşimde Bozulma}

Katılımcılar bu alt temada, COVID-19 pandemisi ile meydana gelen zorunlu ve gönüllü izolasyona bağlı olarak sosyal çevrelerindeki bireylerle etkileşim kurmadıklarını, zorunlu olmadıça evden çıkmadıklarını hatta ebeveynlerinin risk altında olmaları nedeniyle onları bile ziyaret edemediklerini belirtmişlerdir. Katılımcılar, sosyal etkileşimde meydana gelen değişimin kendilerini duygusal ve ruhsal olarak olumsuz etkilediğini ve yalnız hissettiklerini belirtmişlerdir. K-7, pandemi sürecinin sosyal yaşamı üzerindeki etkilerini şu şekilde aktarmıștır:

Pandemi, negatif olarak çok kötü etkiledi. Sosyal hayatımı elimden ald, rahatladığım ve 
sosyalleştiğim arkadaşlarımdan uzaklaştım, yalnızlaştım... İzolasyonun olumlu hiçbir gelişmesini bilmiyorum, hep eksilerini yaşadım. Ben mutluluğumu paylaşarak çoğalttı̆̆ımı, mutsuzluğumu da paylaşarak azalttığımı fark ettim. Bunları yapamadı̆̆ım için bana sadece mutsuzluk bölümü kaldl.

\section{Alt Tema-2: Günlük Yaşam Alışkanlıklarının Değişmesi}

$\mathrm{Bu}$ alt temada katılımcılar, COVID-19 süreci ile birlikte fiziksel, sosyal ve çalışma gibi birçok alanda yaşam alışkanlıkları ve rutinlerinin değiştiğini, rutinlerde meydana gelen değişimler nedeniyle zorladıklarını, stres düzeylerinin arttığını, duygusal ve ruhsal olarak sorunlar yaşadıklarını belirtmiştir. K-11 kodlu katılımcı sürecin etkilerini şu şekilde aktarmıştır:

Olağan bir şeyin tersine yani akışının dışında gitmesi, evlilik hayatını ruhsal anlamda etkiliyor, çünkü bir rutininiz ve alışkanlıklarınız var. Biraz sosyalleşmekte geri kaldık, çocuklar evde çok sikıldılar ve psikolojik olarak zorlandılar. Önceden herkesin belirli bir düzeni vardı. Sabah kalkıyordu herkes, okuluna, işine gidiyordu, akşam toplanılıyordu, gün içerisinde yaptıklarımız bile sohbet oluyordu. Şimdi çocuklar ne yapacă̆ını bilemiyor, teknolojiye bağlandılar ya da çok yemeye bağlandılar. Karışık duygular içindeyiz.

\section{Tema-3: Çocuklar Üzerine Etkiler}

$\mathrm{Bu}$ tema altında, çocuklarda ruhsal ve davranışsal sorunlar ve çocukların eğitim yaşantısında sorunlar alt temaları belirlenmiştir. Alt temalara ilişkin bulgular aşağıda verilmiştir.

\section{Alt Tema-1: Çocuklarda Ruhsal ve Davranışsal Sorunlar}

$\mathrm{Bu}$ alt temada katılımcılar, izolasyon sürecinde çocukların uzun süreli evde kısıtlı kalmasının, günlük yaşamda meydana gelen değişimin ve hasta olmaya yönelik kaygıların çocuklarda ruhsal ve davranışsal sorunlara yol açtığını belirtmişlerdir. Katılımcılardan K-7, çocuklarının yaşadığı sorunu şu şekilde aktarmıştır:

Okulların kapanmastyla çocuklarl tamamen eve kapattım diyebilirim. Üç ay boyunca küçük oğlum hiç merdivenlerden aşă̆l inmedi, bilinçli bir çocuk sürecinin nereye gittiğini iyi kötü tahmin edebiliyor ve tamamen odasina kapand. Büyük oğlum, hastalık derecesinde titiz olmaya başladı. Hastanede çalışıyorum diye daha fazla paranoyak oldu ve hiçbir şekilde bana yaklaşmad, aylardır bana hiç sarılamadı ve hiçbir şekilde temas kurmad.

\section{Alt Tema-2: Çocukların Eğitim Yaşantısında Sorunlar}

Katılımcılar, bu süreçte okulların kapanmasının, uzaktan eğitim sistemine geçilmesinin, sınav sisteminden kaynaklanan belirsizliklerin, yaşanan duygusal ve ruhsal sorunların çocukların evde dersleri takip etmede ve eğitim yaşantısının olumsuz etkilenmesine yol açtığını belirtmişlerdir. K-5, süreçteki deneyimlerini şu şekilde belirtmiştir:

Kızım LGS'ye hazırlandı̆̆ için çok fazla etkilendi, ders çalışmak istemedi ve okuldan çok soğudu. Şimdi pazartesi ve sall okula gidiyor ancak gitmek istemiyor. Ruhsal olarak eve kapanma süreçleri çok etkiledi.

\section{Tema-4: Aile ve Evlilik Yaşantısı Üzerine Etkiler}

$\mathrm{Bu}$ tema altında, aile içi etkileşimde bozulma, çatışma ve ekonomik sorunlar alt temaları elde edilmiştir. Alt temalara ilişskin bulgular aşağıda verilmiştir.

\section{Alt Tema-1: Aile İçi Etkileşimde Bozulma}

$\mathrm{Bu}$ alt temada katılımcılar, süreçte yaşanan zorunlu ya da gönüllü izolasyonun, hastalık sürecine ilişkin kayg1 ve belirsizliğin ortaya çıkardığı duygusal ve ruhsal etkilerin aile içi etkileşim üzerinde önemli etkileri olduğunu belirtmişlerdir. K-8, süreçteki deneyimini şu şekilde belirtmiştir:

Her şeyimiz kusitlı o yüzden de evlilikte mutlaka uzaklaşma oluyor çünkü hepimizde korku ve endişe var. Önceden, bir kahkaha vardl, neşe vardl evin içinde, çocuklar işte dışarıdan geliyordu hep bir arada sohbet vardı maalesef şu anda onu kaybettik. Çocuklar hep evde olduklarl için artık o sohbetimiz kalmadı. Eşim işte dişarıya gidip geldiği için bizden uzak duruyor, odasinı bile ayırlyor. Bir arada olmayı, oturup sohbet etmeyi çok özledik açıkçası.

\section{Alt Tema-2: Çatışma}

$\mathrm{Bu}$ alt temada katılımcılar, uzun süreli evde kalmanın, artan stresin, yaşanan duygusal ve ruhsal zorlanmanın eşler arası çatışma sıklığını artırdığını, bu durumunda evlilik yaşantısı üzerinde sorunlara yol açtığını ve evlilikteki doyumu azalttığını belirtmişlerdir. K-12, süreçte eşiyle yaşadığ çatışma ve anlaşmazlığı şu şekilde aktarmıştır:

Anlaşmazlıklar ve çatışmalarımız oldu. Ben hastalandı̆̆ımda ona bulaşır diye korktu. Ben sessiz biriyim, eşimin söylediklerine cevap vermem. Sen ona laf söylüyorsun o sana laf söylüyor, bunları yaşamamak için elimden geldiği kadar iyi davranmaya çalışırım. Cevap versem ilerleyecek ve şiddete uğramamak için sessiz kaldım. COVID-19 geçirdiğim dönemde eşim beni destekleseydi, sen atlatırsın, başarırsın deseydi benim için dünyaları 
vermiş olurdu. Ancak eşim, "Bana da bulaştırırsan, sen görürsün.” demesi beni çok yıprattı.

\section{Alt Tema-3: Ekonomik Sorunlar}

$\mathrm{Bu}$ alt temada katılımcılar, pandemi nedeniyle iş yerlerinin kapatılması ve işlerin olumsuz etkilenmesi sonucu ekonomik olarak zorlandıklarını belirtmişlerdir. Pandeminin oluşturduğu kaygı ve korkunun yanında yaşanan ekonomik sorunlar aile ve evlilik yaşantısını etkilediği görülmüştür. K-5 kodlu katılımcı süreçte yaşadıkları ekonomik zorluğu şu şekilde aktarmıştır:

Bizim işlerimiz etkilendi, eşim takı işiyle uğraşıyor ve yurt dışına iş yapıyoruz. Bu son noktada takı lüks oldu ve hiçbir şekilde satış olmadl. Işlerimiz çok azaldı ve hazırı yiyoruz uzun zamandır. Artık kenarda ne kadar paramız varsa ona göre tüketim sağllyoruz. Ekonomik zorluklar bizi çok etkiledi. Işslerle alakall eşim çok gergin ve ilk dönemlerde bu gerginliğini eve yansittı, onun gerginliğini hep hissettim. Giderlerimiz devam ederken gelirlerin bir anda durmasi gerçekten kötü, eşimin ve tüm ailenin psikolojisini ve duygusal anlamda bizi çökertti.

\section{Kategori-2: COVID-19 Pandemisinin Aile ve Evlilik Yaşantısı Üzerine Olumlu Etkileri}

Bu kategori altında, yaşam önceliklerinin değişmesi ve yaşamı anlamlandırma ve evlilik yaşantısında eşler arasında paylaşımın artmasına yönelik pozitif yönde gelişim ve değişimi gösteren iki tema belirlenmiştir. Temalara ilişkin bulgular aşağıda verilmiştir.

\section{Tema-1: Yaşam Önceliklerinin Değişmesi ve Yaşamı Anlamlandırma}

COVID-19 pandemisi ile katılımcılar maruz kaldıkları ölüm korkusu, sevdiklerinden uzak kalma, günlük rutinlerdeki değişim ve travmatik yaşantılar sonucunda yaşamlarında önemli farkındalıklar elde ettiklerini belirtmişlerdir. Katılımcılar, yaşam önceliklerinin değiştiğini, daha önceden fark etmedikleri yaşam rutinlerinin kıymetini anladıklarını, bu farkındalıkların aile ve sosyal ilişkileri üzerinde olumlu etkiler oluşturduğunu belirtmişlerdir. K-3, süreçte yaşadığ farkındalığ 1 şu şekilde ifade etmiştir:

Bu süreç, sabrı ögrretti, dışarı çıkabilmenin ne kadar güzel olduğunu, evde sürekli kalmak zorunda olan insanlarin, hastaların durumunu daha iyi anladık. Şükrettik açıkçası, dışarıya çıkabiliyormuşuz eskiden ne kadar güzelmiş dedik. Evlilikte, her zaman karşılıklı anlayıs ve saygı çok önemli ama şu hastalıkta bunu daha iyi anladık, sevdiklerimizin klymetini daha fazla bilememiz gerektiğini anladık. Ufak tefek şeyler için birbirimizi kırmaya değmediğini, her şeyden önce să̆lı̆̆ın geldiğini anladık.

\section{Tema-2: Evlilik Yaşantısında Eşler Arası Paylaşımın Artması}

$\mathrm{Bu}$ tema altında katılımcılar, pandemi sürecinde eşler arası paylaşımın ve desteğin arttığını, süreç ne kadar zor olsa da aile içi birlikte zaman geçirme adına fırsat sağladığını ve bu durumun eşlerin birbirlerine daha sıkı bağlanmalarına ve yakınlaşmalarına yol açtığını belirtmişlerdir. K-1, süreçteki deneyimlerini şu şekilde aktarmıştır:

Eşimle daha fazla vakit geçirdim. Keyifliydi, film izledik, birlikte bir şeyler yaptık, hep beraber yemek yiyebildik, çünkü genelde birlikte yemek yemek bizim için zor oluyor, çalışma saatleri çok değişken eşimin. Bu süreçte bunu bile yapıyor olabilmek bize mutluluk verdi. Eşim, bana çok yardımcı oldu, sanırım bizi birbirimize daha çok bağladı pandemi... Arada bir insanlara ölümün gerçekten var olduğunu hatırlatmak gerekiyor, pandemi bunu çok güzel hatırlattı. O yüzden birbirimize karşı daha anlayışl ve ılımlı olmaya başladık.

\section{TARTIŞMA}

Katılımcılar, hasta olma kaygısı, hasta olduklarında nasıl sorunlarla karşılaşacakları, özellikle çocuğu olan ebeveynler hasta olmaları durumunda çocuklarının bakımını nasıl devam ettirecekleri ve sürecin nasıl devam edeceği konusunda belirsizlik yaşadıklarını ve bu durumunda tedirginlik ve korku duygusunu artırdığını belirtmişlerdir. Bu bağlamda, artan kayg1, stres, belirsizlik ve korkunun aile üyelerini duygusal ve ruhsal olarak olumsuz etkilediği ve evlilik yaşantısında sorunlara yol açtığı bulunmuştur. Literatürdeki araştırma sonuçları değerlendirildiğinde, elde edilen araştırma bulgularını destekler niteliktedir ve COVID-19 pandemisinin toplumdaki bireylerin duygusal ve ruhsal iyilik halini olumsuz etkilediği, stres, depresyon, anksiyete, uyku sorunları ve travma sonrası stres bozukluğu belirtilerine yol açtığ bulunmuştur. ${ }^{14,26,27}$

Olumsuz etkiler kategorisi altında belirlenen ikinci tema ise sosyal ve günlük yaşam üzerine etkiler olmuştur. $\mathrm{Bu}$ tema altında, sosyal etkileşimde bozulma ve günlük yaşam alışkanlıklarının değişmesi alt temaları bulunmuştur. COVID-19 pandemisi, bireyleri sadece fizyolojik olarak değil aynı zamanda ruhsal, sosyal ve spiritüel olarak etkilemiştir. Yaşanan kısıtlamalar, günlük rutinlerin değișmesine, stresle baş etmede önemli bir kaynak olan sosyal destek sistemlerinin azalmasına ve uzun süreli sevdiklerinden ayrı kalmaya yol açmıştır. Sonuç olarak, günlük yaşamdaki hızlı değişimler ve küresel sağlık krizi toplumdaki 
bireylerin ruhsal ve sosyal iyilik hallerini olumsuz etkilemiştir. Literatürdeki araştırmalar, araştırma bulguları ile benzer şekilde pandemi sürecinin günlük rutinleri ve sosyal yaşamı olumsuz etkilediğini göstermektedir. ${ }^{28,29}$ Hastalığın yayılımını önlemek adına uygulanan izolasyon yöntemlerinin, bireylerin uzun süreli ev içerisinde kalmasına, uyku, beslenme, çalışma ve daha birçok günlük rutinlerinin değişmesinin yanında sosyal destek sistemlerinden ayrı kalmaya yol açmıştır. Sosyal destek sistemlerinden ayrı kalma, bireylerin yalnızlık duygusunun artmasina, pandeminin ortaya çıkardığı duygusal ve ruhsal sorunların yaygınlaşmasına yol açmıştır. ${ }^{8,26}$

Pandemi süreci, çocukların bilişsel ve ruhsal gelişim basamakları değerlendirildiğinde, günlük yaşamda meydana gelen değişimler, çocukların ölüm, hastalık ve kayıp gibi birçok kavrama maruz kalmaları ruhsal ve davranışsal olarak olumsuz etkilenmesine yol açtığ1 düşünülmektedir. Literatürdeki araştırma sonuçları değerlendirildiğinde, pandemi sürecinde çocukların internet ve teknolojik araçlara maruz kalma sürelerinin arttığı, uyku alışkanlıklarının olumsuz etkilendiği, anksiyete düzeylerinin, ruhsal ve davranışsal sorunlarının arttığı görülmektedir. ${ }^{30,31}$ Aynı zamanda bu süreçte, ebeveynlerin kaygı ve stres seviyelerinin yüksek olması, ebeveyn çocuk arasındaki ilişkide çatışmaların artmasına, yakınlığın azalmasına ve istismar riskinin ortaya çıkmasına yol açtığ bulunmuştur. $^{32,33} \mathrm{Bu}$ tema altındaki bir diğer alt tema ise çocukların eğitim yaşantısında meydana gelen değişimdir. Pandemi süreci, çocukların bilişsel ve ruhsal gelişiminde önemli yeri olan okulların kapatılmasına, uzaktan eğitim uygulamalarına geçilmesine ve çocukların birçok aktivitelerden geri kalmasına yol açmıştır. Meydana gelen değişim, çocukların akademik başarı düzeyinde azalmaya, okula ve derslere yönelik ilginin azalmasına, aynı zamanda çocukların oyun oynama, akran ilişkileri ve dışarı çıkma aktivitelerinde sorunlara yol açmıştır. ${ }^{31,34}$

Olumsuz etkiler kategorisi altında son olarak, aile yaşantısı üzerine etkiler teması bulunmuş ve bu tema altında aile içi etkileşimde bozulma, çatışma ve ekonomik sorunlar alt temaları belirlenmiştir. Yaşanan sosyal izolasyon, işten çıkartmalar, ekonomik sorunlar, artan stres ve uzun süreli evde kalma katılımcıların ruhsal zorlanmalarına yol açarak eşler arasında çatışmalara ve sorunlara yol açtığı görülmektedir. Eşler arasında yaşanan çatışmalar, etkin yönetilmediğinde şüphesiz aile içi şiddete, evlilik doyumunda azalmaya ve boşanmalara neden olabilmektedir. Literatürdeki araştırmalarda da benzer bulgulara vurgu yapılmış ve COVID-19 pandemisi sürecinde meydana gelen günlük yaşamdaki değişimin, artan stresin, ekonomik sorunların ve sosyal destek sistemindeki yetersizliklerin aile içi çatışma ve şiddet riskini artırdığı ve evlilik doyumunda azalmaya yol açtığı belirtilmiştir. ${ }^{19,35,36}$

COVID-19 pandemisinin aile ve evlilik yaşantısı üzerine olumlu etkileri kategorisi altında yaşam önceliklerinin değişmesi ve yaşamı anlamlandırma ve eşler arası paylaşımın artması olmak üzere iki tema belirlenmiştir. COVİ-19 pandemisinin yol açtığı küresel sağlık krizi ve sosyal izolasyon süreci bireylerin yaşamını olumlu yönde etkileyen değişim ve farkındalıkları beraberinde getirmiştir. Literatürdeki araştırma sonuçları değerlendirildiğinde, COVID-19 pandemi süreci, bireylerin kişisel güç ve yeteneklerini, yakın ilişkilerin önemini ve yaşam önceliklerini fark ettiklerini, zorlu süreçte eşler arası destek ve paylaşımın artmasıyla eşler arasında ilişkilerin güçlenmesi gibi olumlu katkılarının olduğu görülmektedir. Sonuç olarak, COVID-19 pandemisiyle maruz kalınan zorlayıcı ve travmatik yaşantılar insanların yaşamında bir takım gelişim ve değişimi beraberinde getirmiştir. , $^{8,36,37}$

\section{Araştırmanın Sınırlılıkları}

$\mathrm{Bu}$ araştırmanın, bazı sınırlılıkları vardır. İlk sınırlılık, çalışma verilerinin online görüşme programları aracılığı ile toplanmasıdır. Bu nedenle online görüşme programları olmayan katılımcılar araştırmaya dahil edilememiştir. İkinci sınırlılık, araştırma verilerinin toplandığı evli bireylerden en az altı aydır evli olma kriterinin aranması ve altı aydan az süredir evli olan evli bireylerin araştırmaya dahil edilmemesidir. Üçüncü sınırlılık ise araştırma verilerinin tüm evli çiftlere genellenemez olmasıdır. Bu nedenle, COVID-19 pandemisinin aile ve evlilik yaşantısı üzerine etkisini değerlendirmeye yönelik daha geniş örneklemler üzerinde nicel ve karma yöntemlere dayalı araştırmaların yapılması önerilmektedir.

\section{SONUC}

Araştırma sonucunda, COVID-19 pandemisinin aile ve evlilik yaşantısı üzerinde olumsuz ve olumlu olmak üzere bazı etkileri bulunmaktadır. Katılımcılar, COVID-19 pandemi sürecinin, ruhsal, sosyal, çocuklar ve aile yaşantısı alanları üzerinde olumsuz etkileri olduğunu ifade etmişlerdir. Katılımcılar, süreçte ruhsal olarak zorlandıkları alanları, hasta olma, sevdiklerine bulaştırma, belirsizlik, tedirginlik ve korku olarak belirtirken, sosyal etkileşimde bozulmaların meydana geldiğini ve günlük yaşam alışkanlıklarının değiştiğini belirtmişlerdir. Aynı zamanda katılımcılar, pandemi sürecinin aile yaşantısı, evlilik ve çocuklar üzerinde bir takım olumsuz etkilere yol açtığını aktarmışlardır. Katılımcılar, çocukların eğitim yaşantısında meydana gelen sorunların, sosyal etkileşimde bozulmaların ve pandemi sürecine bağlı olarak günlük yaşamdaki değişimlerin çocuklarda 
ruhsal ve davranışsal sorunlara yol açtığını belirtmişlerdir. Aynı zamanda katılımcılar, pandemi sürecinde, aile içi etkileşimde bozulmaların olduğunu, eşler arası çatışmaların arttığını ve ekonomik sorunların yaşandığını, bu durumun da aile ve evlilik yaşantısı üzerinde olumsuz etkilere yol açtığını aktarmışlardır. Bu bağlamda, küresel bazda yaşanan COVID-19 krizi ve sosyal izolasyon uygulamalarının aile ve evlilik yaşantısı üzerine fiziksel, ruhsal ve sosyal olmak üzere birçok olumsuz etkileri vardır. Bu nedenle, aile ile çalışan sağlık profesyonellerinin, ailelerin ve eşlerin bu süreçteki bilgi gereksinimlerinin ve yaşadığı zorlukların belirlemesi, zorluklara yönelik baş etme becerilerinin, aile içinde ve eşler arasında etkili iletişim becerilerinin geliştirilmesi COVID-19 pandemisinin etkilerini en aza indirecektir. Ayn zamanda, gereksinim duyan ailelerin aile terapistlerine ya da ruh sağlığı uzmanlarına yönlendirilerek yaşanan sorunların kronikleşmemesi için koruyucu önlemlerin alınması önemli olacaktır. Araştırmada, pandemi sürecinin sadece aile ve evlilik yaşantısında olumsuz etkilere yol açmadığı aynı zamanda katılımcılar bu süreçte yaşam önceliklerinin değiştiğini, yaşamın anlamı ve önemini fark ettiklerini ve eşler arasında paylaşımın arttığı bulunmuştur. Araştırma sonuçlarında yer aldığı gibi bu süreçte evli çiftlerin bazı farkındalıklar kazandıkları görülmüştür. Bu bağlamda, bireylerin farkındalıklarının desteklenmesi, bu farkındalıkların aile ve evlilik yaşantısına aktarılması aile ve evlilik yaşantısı üzerinde olumlu değişime katk1 sağlayacaktır.

\section{Çıkar Çatışması}

Araştırmacılar, bu araştırma için çıkar çatışması belirtmemişlerdir.

\section{Finansal Destek}

Araştırmacılar, bu araştırmanın gerçekleştirilmesinde herhangi bir kurum ve kuruluştan maddi destek almamıştır.

\section{KAYNAKLAR}

1. Bozkurt Y, Zeybek Z, Așkın R. COVID-19 pandemisi: Psikolojik etkileri ve terapötik müdahaleler. İstanbul Ticaret Üniversitesi Sosyal Bilimler Dergisi 2020; 19(37): 304-318.

2. Song F, Shi N, Shan F, Zhang Z, Shen J, Lu H, et al. Emerging 2019 novel coronavirus (2019-nCoV) pneumonia. Radiology 2020; 295(1): 210-217. Doi: 10.1148/radiol.2020200274

3. Cucinotta D, Vanelli M. WHO declares COVID-19 a pandemic. Acta Biomedica 2020; 91(1): 157-160. Doi: 10.23750/abm.v91i1.9397.

4. World Health Organization (WHO). WHO/Europe, Coronavirus disease (COVID-19) outbreak - WHO announces COVID-19 outbreak a pandemic, 2020.https://www.euro.who.int/en/health- topics/health-emergencies/coronavirus-covid-19\#. Erişim Tarihi: 17 Ocak 2021

5. Koçak Z, Harmancı H. COVID-19 pandemi sürecinde ailede ruh sağlığı. Karatay Sosyal Araştırmalar Dergisi 2020; 5: 180-204.

6. Balcı Y, Çetin G. COVID-19 pandemi sürecinin Türkiye'de istihdama etkileri ve kamu açısından alınması gereken tedbirler. İstanbul Ticaret Üniversitesi Sosyal Bilimler Dergisi 2020; 19(37): 40-58.

7. Chinazzi M, Davis JT, Ajelli M, Gioannini C, Litvinova M, Merler S, et al. The effect of travel restrictions on the spread of the 2019 novel coronavirus (COVID-19) outbreak. Science 2020; 368(6489): 395-400. Doi: 10.1126/science.aba9757.

8. Karataş Z. COVID-19 pandemisinin toplumsal etkileri, değişim ve güçlenme. Türkiye Sosyal Hizmet Araştırmaları Dergisi 2020; 4(1): 3-17.

9. Öztürk MS, Yilmaz N, Erbil DD, Hazer O. COVID-19 pandemi döneminde hane halkındaki çatıșma ve birlik-beraberlik durumunun incelenmesi. Electronic Turkish Studies 2020; 15(4): 295-314. Doi: 10.7827/TurkishStudies.44424.

10. Yavuz K. COVID-19 salgınının sosyal politikanın geleceği üzerine etkileri. Sosyal Bilimler Dergisi 2020; 7 (45), 181- 193. Doi: 10.29228/SOBIDER.42843

11. Centers for Disease Control and Prevention (CDC). Coronavirus disease 2019 (COVID-19), 2020. https://www.cdc.gov/coronavirus/2019ncov/prevent-getting-sick/how-covid-spreads.html Erişim Tarihi: 13.01.2021.

12. Alfawaz HA, Wani K, Aljumah AA, Aldisi D, Ansari MG, Yakout SM, et al. Psychological well-being during COVID-19 lockdown: Insights from a Saudi State University's Academic Community. Journal of King Saud University-Science 2021; 33(1): 101262. Doi: $10.1016 /$ j.jksus.2020.101262

13. Gulati G, Kelly BD. Domestic violence against women and the COVID-19 pandemic: What is the role of psychiatry? International Journal of Law and Psychiatry 2020; 71: 101594. Doi: 10.1016/j.ijlp.2020.101594.

14. Huang Y, Zhao N. Generalized anxiety disorder, depressive symptoms and sleep quality during COVID-19 outbreak in China: A web-based crosssectional survey. Psychiatry Research 2020; 288: 112954. Doi: 10.1016/j.psychres.2020.112954.

15. Orru G, Ciacchini R, Gemignani A, Conversano C. Psychological intervention measures during the COVID-19 pandemic. Clinical Neuropsychiatry 2020; 17(2): 76-79. Doi: 10.36131/CN20200208

16. Ünal B, Gülseren L. COVID-19 pandemisinin görünmeyen yüzü: Aile içi kadına yönelik şiddet. Klinik Psikiyatri Dergisi 2020; 23: 89-94.

17. Akbaş ÖZ, Dursun C. Koronavirüs (COVID-19) pandemisi sürecinde özel alanına kamusal alanı sı̆̆dıran çalışan anneler. Avrasya Sosyal ve Ekonomi Araştırmaları Dergisi 2020; 7(5): 78-94.

18. Ergönen AT, Biçen E, Ersoy G. COVID-19 salgınında ev içi şiddet. The Bulletin of Legal Medicine 2020; 25: 48-57. doi:10.17986/blm.2020.v25i.1408

19. Usher K, Bhullar N, Durkin J, Gyamfi N, Jackson D. Family violence and COVID-19: Increased vulnerability and reduced options for support. International Journal of Mental Health Nursing 2020; 29(4):549-552. Doi: 10.1111/inm.12735 
20. Pieh C, O'Rourke T, Budimir S, Probst T. Relationship quality and mental health during COVID-19 lockdown. PLoS One 2020; 15(9): e0238906. Doi: 10.1371/journal.pone.0238906.

21. Zhang $H$. The influence of the ongoing COVID-19 pandemic on family violence in China. Journal of Family Violence 2020. Doi: 10.1007/s10896-02000196-8

22. Cao W, Fang Z, Hou G, Han M, Xu X, Dong J, et al. The psychological impact of the COVID-19 epidemic on college students in China. Psychiatry Research 2020; 287: $112934 . \quad$ Doi: 10.1016/j.psychres.2020.112934.

23. Creswell, J. W. (2013). Qualitative inquiry and research design: Choosing among five approaches. 3. Bask1. Sage Publicatios. s: 65-110.

24. Tong A, Sainsbury P, Craig J. Consolidated criteria for reporting qualitative research (COREQ): A 32-item checklist for interviews and focus groups. International Journal for Quality in Health Care 2007; 19(6): 349-357. Doi: 10.1093/intqhe/mzm042.

25. Connelly LM. Trustworthiness in qualitative research. Medsurg Nursing 2016; 25(6): 435436.

26. Shevlin M, McBride O, Murphy J, Miller JG, Hartman TK, Levita L, et al. Anxiety, depression, traumatic stress and COVID-19-related anxiety in the UK general population during the COVID-19 pandemic. BJPsych Open 2020; 6(6):e125. Doi: 10.1192/bjo.2020.109

27. Zhu Z, Liu Q, Jiang X, Manandhar U, Luo Z, Zheng $X$, et al. The psychological status of people affected by the COVID-19 outbreak in China. Journal of Psychiatric Research 2020; 129: 1-7. Doi: 10.1016/j.jpsychires.2020.05.026

28. Hwang TZ, Rabheru K, Peisah K, Reichman W, Ikeda M. Loneliness and social isolation during the COVID-19 pandemic. International Psychogeriatrics 2020; 32(10): 1217-1230.doi: $10.1017 / \mathrm{S} 1041610220000988$

29. Banerjee D, Rai M. Social isolation in COVID-19: The impact of loneliness. International Journal of
Social Psychiatry 2020; 66(6): 525-527. Doi: 10.1177/0020764020922269

30. Di Giorgio E, DiRiso D, Mioni G, Cellini N. The interplay between mothers' and children behavioral and psychological factors during COVID-19: An Italian study. European Child \& Adolescent Psychiatry 2020;1-12. Doi: 10.1007/s00787-02001631-3

31. Zengin M, Yayan EH, Vicnelioğlu E. The effects of the COVID-19 pandemic on children's life styles and anxiety levels. Journal of Child and Adolescent Psychiatric Nursing 2021; 1-7. Doi: 10.1111/jcap. 12316

32. Brown SM, Doom JR, Lechuga-Peña S, Watamura SE, Koppels T. Stress and parenting during the global COVID-19 pandemic. Child Abuse \& Neglect 2020; 110(2): 104699. Doi:10.1016/j.chiabu.2020.104699

33. Russell BS, Hutchison M, Tambling R, Tomkunas, AJ, Horton, AL. Initial challenges of caregiving during COVID-19: Caregiver burden, mental health, and the parent-child relationship. Child Psychiatry\& Human Development 2020; 51, 671-682. Doi: 10.1007/s10578-020-01037-x

34. Cluver L, Lachman JM, Sherr L, Wessels I, Krug E, Rakotomalala S, et al. Parenting in a time of COVID19. Lancet 2020; 395(10231). Doi: 10.1016/S01406736(20)30736-4

35. Campbell AM. An increasing risk of family violence during the COVID-19 pandemic: Strengthening community collaborations to save lives. Forensic Science International Reports 2020; 2: 100089. Doi: 10.1016/j.fsir.2020.100089

36. Prime $\mathrm{H}$, Wade M, Browne DT. Risk and resilience in family well-being during the COVID-19 pandemic. American Psychologist 2020;75(5): 631643. Doi: 10.1037/amp0000660.

37. $\mathrm{Yu} \mathrm{Y,} \mathrm{Li} \mathrm{B.} \mathrm{Effects} \mathrm{of} \mathrm{mindfulness} \mathrm{and} \mathrm{meaning} \mathrm{in}$ life on psychological distress in Chinese university students during the COVID-19 epidemic: A chained mediation model. Asian Journal of Psychiatry 2020; 53. Doi: 10.1016/j.ajp.2020.102211. 